Note

\title{
Visual soil structure quality assessment on Oxisols under no-tillage system
}

\author{
Neyde Fabíola Balarezo Giarola1*; Alvaro Pires da Silva²; Cássio Antônio Tormena³ \\ Bruce Ball ${ }^{4}$; Jadir Aparecido Rosa ${ }^{5}$ \\ ${ }^{1}$ UEPG - Depto. de Ciência do Solo e Engenharia Agrícola, Av. Gal. Carlos Cavalcanti, 4748 - 84030-900 - \\ Ponta Grossa, PR - Brasil. \\ ${ }^{2} U S P / E S A L Q$ - Depto. de Ciência do Solo, C.P. 9 - 13418-900 - Piracicaba, SP - Brasil. \\ ${ }^{3} U E M$ - Depto. de Agronomia, Av. Colombo, 5790 - Maringá, PR - Brasil. \\ ${ }^{4} S A C-$ Dept. Plant E Soil Science - Edinburgh, EH9 3JG - United Kingdom. \\ IAPAR/Pólo Regional de Pesquisa de Ponta Grossa, BR 376, km 496, C.P. 129 - 84001-970 - Ponta Grossa, \\ $P R-$ Brasil. \\ *Corresponding author <neydef@uepg.br>
}

\begin{abstract}
Methods for evaluation the soil structure quality based on field evaluations are useful to determine strategies for soil management, with the advantage of requirement the use of little equipment and the possibility of immediate interpretation. A new methodology was recently developed to temperate soils for this purpose, called Visual Soil Structure Assessment (Ball et al., 2007). It was tested the hypothesis that it is possible to apply and advance in the interpretation of the results from use of Visual Soils Structure Assessment in cultivated Oxisols. Therefore the goal of this study was to apply, evaluate and enhance the potential of the methodology developed by Ball et al. (2007) in two Oxisols under long-term, no-till in Parana State, Brazil, as well as in a soil under native forest, used as reference of soil structural quality. The proposed implementation and progress in terms of structural quality for the distinct layers provided an assessment of soil physical quality more practical and detailed. This is useful to support the selection of appropriate techniques for mechanical and biological management systems in order to achieve the physical quality of soil suitable for crop development. Visual scores of soil structure quality proposed by Ball et al. (2007) can be applied to Brazilian Oxisols cultivated under no-tillage system.
\end{abstract}

Key words: soil physical quality, soil morphological analysis, soil conservation management

\section{Avaliação visual da qualidade da estrutura do solo em Latossolos sob sistema plantio direto}

\begin{abstract}
RESUMO: Métodos para avaliação da qualidade da estrutura do solo baseados em avaliações de campo são úteis para estabelecer estratégias de manejo do solo, com a vantagem de exigirem a utilização de poucos equipamentos e a possibilidade de interpretações imediatas. Recentemente foi desenvolvido um novo método com este objetivo para solos de clima temperado, denominado Avaliação Visual da Estrutura do Solo (Ball et al., 2007). Testou-se a hipótese que é possível aplicar e avançar na interpretação dos resultados obtidos por meio da Avaliação Visual da Estrutura do Solo em Latossolos cultivados. Para tanto avaliou-se o potencial de utilização da metodologia desenvolvida por Ball et al. (2007) em dois Latossolos sob plantio direto de longa duração no Estado do Paraná, Brasil, bem como em um solo sob floresta nativa, utilizado como referência de qualidade estrutural do solo. A hipótese foi confirmada, uma vez que a aplicação e o avanço proposto, em termos de qualidade estrutural para as diferentes camadas do solo permitiram uma avaliação da qualidade física mais prática e detalhada, além de útil como suporte para selecionar técnicas apropriadas de manejo mecânico e biológico com o intuito de alcançar a qualidade física do solo adequada para o desenvolvimento das culturas. Os escores visuais de qualidade da estrutura do solo propostos por Ball et al. (2007) podem ser aplicados a Latossolos brasileiros cultivados sob sistema plantio direto.

Palavras-chave: qualidade física do solo, análise morfológica do solo, sistema de manejo conservacionista
\end{abstract}

\section{Introduction}

Soil structure is related to plant growth and crop response because it dictates water availability, aeration and mechanical resistance to root growth. Degradation of soil structure implies the physical degradation of the soil sys- tem and a consequent decrease in agroecosystem productivity (Gale et al., 2000; Kay and Angers, 2001).

Evaluation of soil structure is usually done using quantitative parameters, such as soil density and porosity, characteristic water retention curves and soil resistance to root growth. Recently, methods to evaluate soil 
structure based on field measurements were developed for temperate soils (Shepherd, 2000; McKenzie, 2001; Ball and Douglas, 2003; Roger-Estrade et al., 2004; Ball et al., 2007). These field evaluations help farmers and professionals decide on the best soil management practice by providing immediately interpretable results without the need for a great deal of equipment. On the other hand, similar methodologies were not yet developed for tropical soils and a few techniques from Europe have been applied in Brazil (Tavares Filho et al., 1999; Fregonezi et al., 2001; Giarola et al., 2009).

Most field methods for assessing soil structure quality were based on a scale developed by Peerlkamp (1959). Due to the restrictions presented by this test, Ball et al. (2007) revised and updated the Peerlkamp procedures to a more practical and objective process. The method employs a soil volume $25 \mathrm{~cm}$ deep, $15 \mathrm{~cm}$ thick and as wide as a spade blade (about $25 \mathrm{~cm}$ ) (Ball et al., 2007). The criteria for classifying the structural quality are based on morphology, resistance, presence of roots inside and outside aggregates, and number and size of visible pores. Aggregates are graded according to those observations and the final score is computed by averaging the grades weighted by the thickness of the layer where they occur and fitting them into the chart of structural quality (Ball et al., 2007). This study tested the hypothesis that scoring the layers separately (instead of scoring the whole soil volume) would improve the use of the method as a diagnostic criterion of soil structure quality. The objective of this work is to assess and compare the performance of the method described by Ball et al. (2007) and the modified method of interpretation proposed here in two Oxisols from Paraná State, Brazil, under long-term no-tillage system.

\section{Material and Methods}

This study was done in Ponta Grossa, Parana State, Brazil (25 $03^{\prime}$ and $25^{\circ} 09^{\prime} \mathrm{S}$; $50^{\circ} 18^{\prime}$ and $\left.50^{\circ} 06^{\prime} \mathrm{W}\right)$. The Ponta Grossa region has a gently sloping landscape, with altitudes from 800 to $1,100 \mathrm{~m}$ above sea level, an average annual temperature of $18^{\circ} \mathrm{C}$ and a mean of $1,400 \mathrm{~mm}$ of precipitation. Climate, according to the Köppen system, is Cfa (subtropical moist mesothermic). Two soils were sampled: a Typic Dystrudox (No-till loam with $150 \mathrm{~g}$ $\mathrm{kg}^{-1}$ clay, $100 \mathrm{~g} \mathrm{~kg}^{-1}$ silt and $750 \mathrm{~g} \mathrm{~kg}^{-1}$ sand; and a Typic Acrudox (No-till clay), with $710 \mathrm{~g} \mathrm{~kg}^{-1}$ clay, $150 \mathrm{~g} \mathrm{~kg}^{-1}$ silt and $140 \mathrm{~g} \mathrm{~kg}^{-1}$ sand.

At the Typic Dystrudox, sampling was done in 0.5 ha of a grain production area, managed under no-till system for the past 15 years. The crop rotation was black oats and vetch, wheat or oats during the winter, and soybean, corn or beans during the summer. At the time of sampling, fields were cultivated with wheat. At Typic Acrudox, two sites ( 0.5 ha each) were sampled: i) a grain production area managed under no-till system for twenty three years, with rye, wheat, black oats or vetch during the winter and soybean, corn or beans during the summer; ii) a sixty-year-old secondary forest.
In each area, ten points were sampled randomly, using the visual method proposed by Ball et al. (2007) (henceforth Ball method). We did a modification in the Ball's method application, scoring the different layers to provide a more detailed evaluation of the soil structural quality. The block was measured on the spade and layers identified by looking for the structural discontinuity which usually occurred at $5-15 \mathrm{~cm}$ depth below the soil surface. The layer above and below this depth was examined and given a score. Morphology, resistance to break-up by hand and structural characteristics of a soil volume were evaluated and graded visually $(\mathrm{Sq})$ from 1 (best structural quality) to 5 (worst structural quality). Averages were compared using the method described by Gabriel (1978), in accord to SAS (2001) to calculate confidence intervals of means.

\section{Results and Discussion}

Contrasting morphological characteristics were observed after the structural units were obtained from the soil volumes extracted. Aggregates from the forest site were easily broken, smaller than $6 \mathrm{~mm}$ (diameter), very porous and the roots were wholly distributed in soil. In the cultivated areas, it was more difficult to break down the soil volume into aggregates, these were larger than those from the forest, less porous and the roots were concentrated around the aggregates and cracks between aggregates. Also, most of the porosity was in macropores and cracks between aggregates.

Although more difficult to break down, aggregates from No-till clay were smaller than the No-till loam, particularly in the upper $10 \mathrm{~cm}$. In the No-till loam, fragments greater than $5 \mathrm{~cm}$ were found along the whole thickness of the sampling volume. The average scores of structural quality according to the Ball method are in Figure 1.

The decrease in the structural quality between forest and the no-till systems was observed in the average score Sq among them. The No-till clay resulted in a lower average $\mathrm{Sq}$ as compared to No-till loam, probably

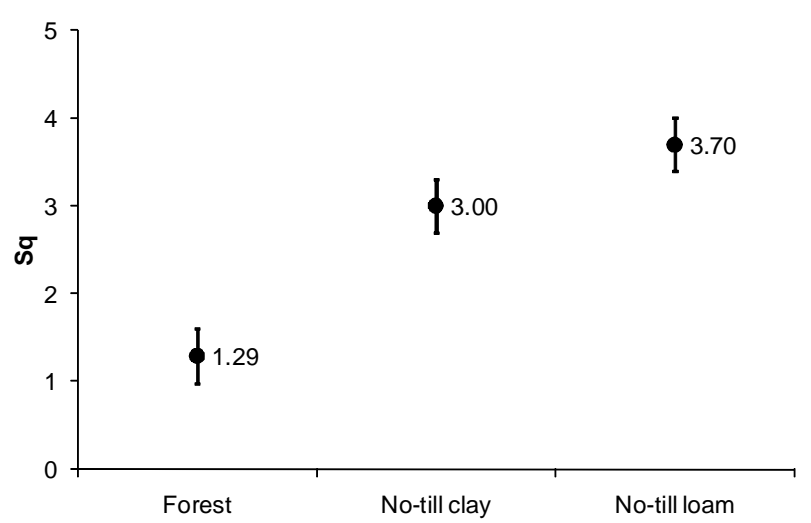

Figure 1 - Average score of structural quality (Sq) of the Forest, No-till clay and No-till loam Oxisols. Bars are the confidence intervals $(p<0.05)$ and averages are different when bars do not overlap. 
due to the greater resistance and resilience of the Notill clay structure to mechanical stress (Blanco-Canqui and Lal, 2008). Among the factors that account for such differences between No-till clay and No-till loam are the greater clay content and carbon content (No-till clay = $6 \%$ and No-till loam $=2.5 \%$ ), as well as structure recovery due to dry-wet cycles in the No-till clay. Better soil fertility in No-till clay provides more effective root growth in the sampled layer and influenced positively the soil structure. In addition, the use of the no-till system for a longer time (25 years in the No-till clay and 15 years in the No-till loam) and a greater number of cover crops during the winter in the No-till clay may accounted for the these results.

The Sq scores between 1.0 and 2.0 mean good structural quality, between 2.0 and 3.0, intermediate, and between 3.0 and 5.0, a degraded soil structure according to Ball et al. (2007). The No-till clay and No-till loam Sq scores put them at the limit of degraded soils, suggesting that action should be taken to recover the sustainable function of the soil system. In clayey Oxisols from northwestern Parana and under conservation management, Giarola et al. (2009) also determined scores of soil structure quality indicating limitation or degradation.

The Ball method proposes an analysis of the whole soil volume down to a depth of $25 \mathrm{~cm}$, resulting in a single score for the structural quality of the sample based on the weighted average of scores of each layer in the sampled soil volume (Figure 1). However, a separate analysis of the layers identified during the field work, which will be discussed, may contribute with relevant information about the consequences of the longterm no tillage used in these soils.

The averaged scores of two layers identified in the samples (layers 1 and 2) (Figures 2 and 3) shows the average thickness of layer 1 for the three sampling sites (Figure 4). The averaged score of the forest soil for both layers (modified Ball method) were in the same interval as the score for the whole volume of forest soil (Ball

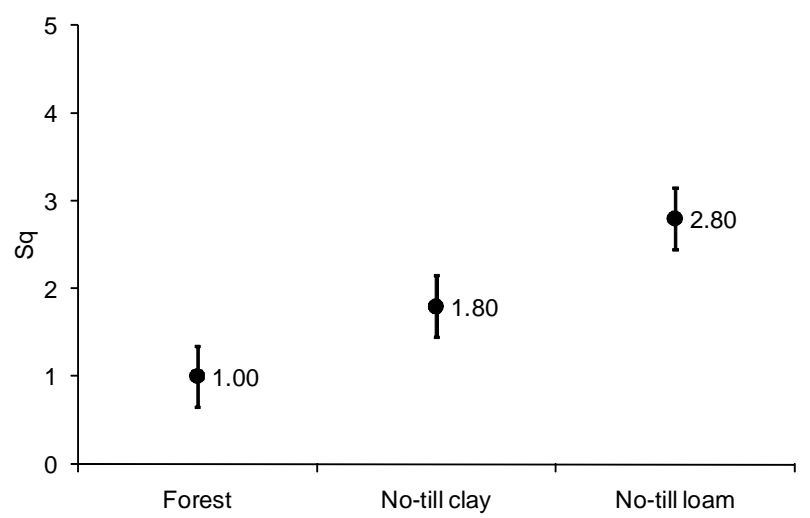

Figure 2 - Average score of structural quality (Sq) of layer 1 of the clayey Oxisol under Forest, No-till clay and Notill loam Oxisols. Bars are the confidence interval $(p<0.05)$ and averages are different when bars do not overlay.

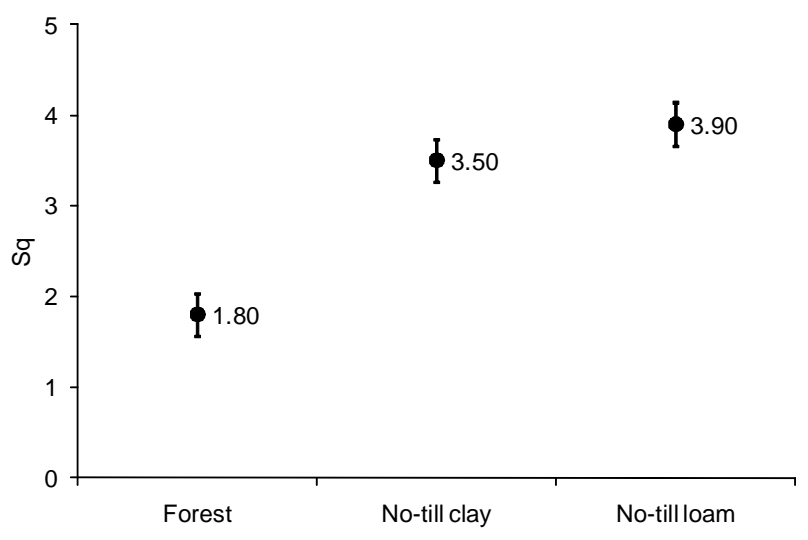

Figure 3 - Average score of structural quality (Sq) of layer 2 of the clayey Oxisol under Forest, No-till clay and Notill loam Oxisol. Bars are the confidence interval $(p<0.05)$ and averages are different when bars do not overlay

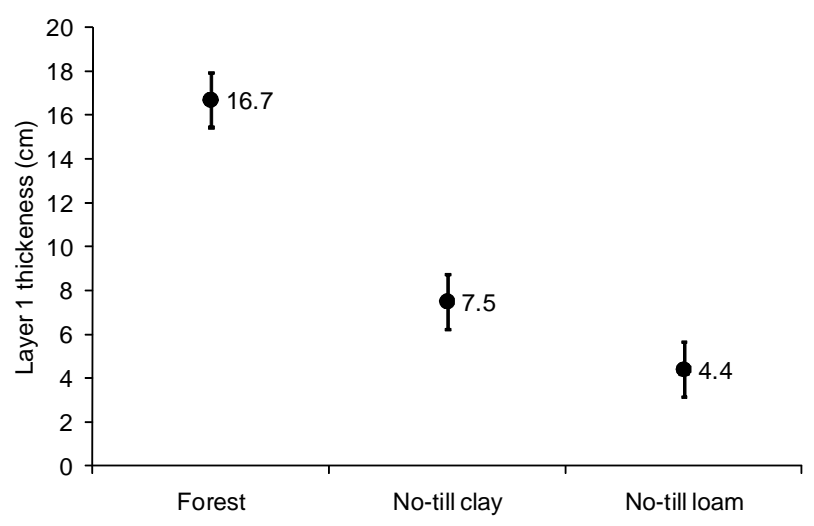

Figure 4 - Average thickness of layer 1 for the clayey Oxisol under Forest, No-till clay and No-till loam Oxisols. Bars are the confidence interval $(p<0.05)$ and averages are different when bars do not overlay.

method), i.e., that of good structural quality (Ball et al., 2007). In the No-till clay, an abrupt change in the scores could be observed between layer 1 and layer 2, from good $(\mathrm{Sq}=1.8)$ to degraded $(\mathrm{Sq}=3.5)$ structural quality. The same was observed in the No-till loam, where layer 1 had $\mathrm{Sq}=2.8$ (intermediate quality), and layer 2 had $\mathrm{Sq}=3.9$ (degraded quality). The contrast between layer 1 and layer 2 was greater in the No-till clay, despite that structural quality was smaller in whole sample soil in No-till loam. Those abrupt changes in soil conditions verified in No-till clay may imply larger decreases in root growth than gradual changes (Clark et al., 2008).

A procedure to represent the volume or depth at which the root growth would not be affected by the soil physical quality was not explored by Ball et al. (2007). This improvement is proposed here (as the modified Ball method), and its representation is shown in Figure 5, based on the Sq's in the layers and converted to percentage. This conversion was done taking the depth of 25 as $100 \%$. Therefore, in the forest, $100 \%$ of the sample (i.e., 


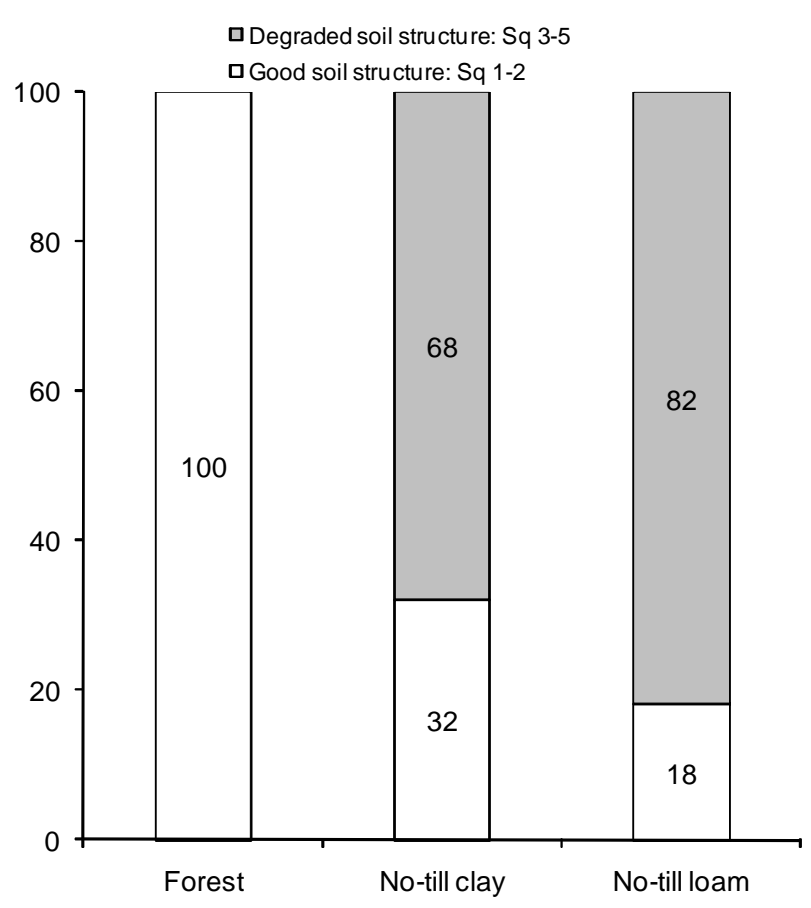

Figure 5 - Percentage of the sample thickness with distinct structural quality, according to criteria of Ball et al. (2007) in samples taken in clayey Oxisol under Forest, No-till clay and No-till loam Oxisols.

down to $25 \mathrm{~cm}$ depth) had good structural quality. For the No-till clay, only the first $8 \mathrm{~cm}(32 \%)$ had good structural quality, as the remaining $17 \mathrm{~cm}(68 \%)$ was classified as degraded. In the No-till loam, the case was worst. The first $5 \mathrm{~cm}(18 \%)$ were scored as having good structural quality. An alternative procedure is to represent the percentage of soil volume explored by the root system. The representation of data as in Figure 5 presents a more practical and objective way to depict the quality of soil structure, facilitating the selection of mechanical or biological practices to improve the physical quality of soil as well as to define where take samples for more detailed quantitative analyses.

\section{Conclusions}

The hypothesis was confirmed, since the procedure described by Ball et al. (2007) was sensitive enough to identify changes in structural quality of Oxisols under different management and the modification proposed may be seen as a more practical and objective evaluation of the physical quality of soil to better support the selection of mechanical and biological practices best suitable for plant growth.

\section{References}

Ball, B.C.; Batey, T.; Munkholm, L.J. 2007. Field assessment of soil structural quality: a development of Peerlkamp test. Soil Use and Management 23: 329-337.

Ball, B.C.; Douglas, J.T. 2003. A simple procedure for assessing soil structural, rooting and surface conditions. Soil Use and Management 19: 50-56.

Blanco-Canqui, H.; Lal, R. 2008. Axle-load impacts on hydraulic properties and corn yield in no-till clay and silt loam. Agronomy Journal 100: 1673-1680.

Clark, L.J.; Ferraris, S.; Price, A.H.; Whalley, W.R. 2008. A gradual rather than abrupt increase in soil strength gives better root penetration of strong layers. Plant and Soil 307: 235-242.

Fregonezi, G.A.F.; Brossard, M.; Guimarães, M.F.; Medina, C.C. 2001. Morphological and physical transformation in a clayey Oxisol under pastures. Revista Brasileira de Ciência do Solo 25: 1017-1027. (in Portuguese, with abstract in English).

Gabriel, K.A. 1978. Simple method of multiple comparisons of means. Journal of the American Statistical Association 73: 724729.

Gale, W.J.; Cambardella, C.A; Bailey, T.B. 2000. Surface residue and root derived carbon in stable and unstable aggregates. Soil Science Society of America Journal 64: 196-201.

Giarola, N.F.B.; Tormena, C.A.; Silva, A.P.; Ball, B. 2009. Visual assessment soil quality structure methodology applied to Oxisol under different soil use and management. Ciência Rural 39: 2531-2534. (in Portuguese, with abstract in English).

Kay, B.D.; Angers, D.A. 2001. Soil Structure. In: Sumner, M.E., ed.. Handbook of Soil Science. CRC Press, Boca Raton, Florida, FL, USA. p.229-276.

Mckenzie, D.C. 2001. Rapid assessment of soil compaction damage. I. The SOILpak score, a semi-quantitative measure of soil structural form. Australian Journal of Soil Research 39: 117-125.

Peerlkamp, P.K. 1959. A visual method of soil structure evaluation. Meded. v.d. Landbouwhogeschool en Opzoekingsstations van de Staat te Gent. XXIV 24: 216-221.

Roger-Estrade, J.; Richard, G.; Caneill, J.; Boizard, H.; Coquet, Y.; Defossez, P.; Manichon, H. 2004. Morphological characterization of soil structure in tilled fields: from a diagnosis method to the modeling of structural changes over time. Soil \& Tillage Research 79: 33-49.

SAS Institute. 2001. SAS/STAT User's Guide; Version 8.2 Cary: SAS Institute, NC, USA. 943p.

Shepherd, T.G. 2000. Visual Soil Assessment: Field Guide for Cropping and Pastoral Grazing on Flat to Rolling Country. Horizons.mw \& Landcare Research, Palmerston North, New Zealand.

Tavares Filho, J.; Ralisch, R.; Guimarães, M.F.; Medina, C.C.; Balbino, L.C.; Neves, C.S.V.J. 1999. Cultural profile methodology for soil physical evaluation under tropical conditions. Revista Brasileira de Ciência do Solo 23: 393-399 (in Portuguese, with abstract in English).

Received June 26, 2009

Accepted April 01, 2010 